\title{
SHORTER PAPERS
}

\section{Some preliminary evidence on employee share ownership schemes in New Zealand listed companies}

\author{
Michael Firth+, Stephen Keef and Ross Mear*
}

This note examines employee share ownership schemes as approved by the Commissioner of the Inland Revenue Department under the provisions of section 166 of the 1976 Income Tax Act. The note provides preliminary evidence on the characteristics of these section 166 schemes, including an analysis of the participation rates and the benefits conferred.

\section{Introduction}

Since the early 1970 s, worker participation in management in New Zealand has received considerable attention in the business and industrial relations literature (Fogelberg, 1975; Kirk, 1984: Smith, 1978, 1979a and 1979b; Stephens, 1982; Trott, 1977; Turkington, 1980; and Young, 1978). The general consensus from these studies is that, despite New Zealand's reputation for wide-ranging advances in the social field, developments in worker participation have been limited relative to the progress evident in other industrial democracies.

In an attempt to explain the absence of any significant progress in the extension of workers' rights and worker participation in decision-making. critics identify 3 mutually confounding factors. First, New Zealand's strong tradition of conciliation and arbitration has hindered the development of direct bargaining between employer and employee. Second, is the unwillingness of respective governments to introduce legislation which directly promotes worker participation in decision making; and third, is the difference between employer and employee perceptions of worker participation. Employers, it would appear, perceive worker participation as a means of improving productivity through increased employee involvement and commitment to managerial objectives, whereas trade unionists view worker participation as a philosophy embodying certain rights to the employee. This view emphasises the joint or mutual participation of workers in a variety of personnel, social and economic decisions.

Despite this apparent lack of progress, one form of worker participation in which the Government has initiated legislation is in the area of employee share ownership. The original legislation was incorporated in the Companies Empowering Act 1924 and subsequently revised and extended in the 1976 Income Tax Act. Whilst this latter legislation has been effective for a decade, comparatively little is known about the extent to which employers and employees have utilised the provisions of the Act.

Within this context, the purpose of this note is to provide preliminary evidence on employee share ownership in New Zealand. Research emphasis focuses on companies listed on the New Zealand Stock Exchange which have effected employee share ownership schemes as approved by the Commissioner of the Inland Revenue Department (IRD) under the provisions of section 166 of the 1976 Income Tax Act. 


\section{Legislative details}

Section 69 of the Income Tax Act 1976 states that benefits received by employees from share purchases or options in respect of present or future services form part of their assessable income. Whilst section 64 itself provides for limited exemptions, the major exception to the principle established by section 69 is contained in section 166 of the Act (hereafter s166) entitled "Notional interest on loans made to employees under employee share purchase scheme".

In essence, s166 allows companies to make loans to their employees to enable them to purchase shares in their employer. The scheme must be approved by the Commissioner of the IRD and requires all shares to be offered to each class of employee, that is, full-time or parttime, on the same basis. Relevant legislative details include:

(a) the scheme must operate for a minimum period of 3 years:

(b) the shares must be fully paid up ordinary capital of the employer;

(c) directors and associated persons are specifically excluded;

(d) the shares must be offered to employees at a price which is not greater than the market value on the date of issue;

(e) a limit of $\$ 2340$ is imposed upon the total cost of the shares purchased by each employee";

(f) all loans made under the scheme must be free of all interest and other charges;

(g) where funds are advanced to employees, repayment is to be undertaken in regular weekly, fortnightly or monthly instalments.

The shares are held by a Trustee for the minimum specified period whilst dividends on the shares must be paid directly to the employee shareholder and form part of their assessable income. The treatment of rights and bonus issues is not directly addressed by the legislation and the treatment would depend, to a great extent. on how the Trustee interpreted the legislation. At the end of the term of the scheme, when full repayment has been made, the Trustee will transfer direct ownership to the employee.

S166 confers potential tax benefits to both employers and employees. Employees obtain a non-taxable benefit from participation to the extent that the issue price discount and the interest free loan do not form part of their assessable income. Similarly the company also obtains some taxation relief. The company is entitled to claim a notional interest deduction, calculated with monthly rests, at the rate of 10 percent per annum on the amount of outstanding employee loans and may be claimed for up to 5 years after the date of the advance.

\section{Method}

Communications with the IRD revealed an unwillingness to disclose the names of companies operating approved share schemes on the basis it violated section 13 of the Inland Revenue Department Act 1974. Nevertheless, the IRD did provide the number of schemes approved, rather than implemented, each year throughout the period 1976-1985.

To obtain information on implemented schemes the personnel managers of the 212 companies listed on the New Zealand Stock Exchange were surveyed in 1984. The postal questionnaire comprised 4 distinct sections; covering characteristics of the company, details of the scheme, reasons for the scheme and employers' general perceptions as to the effects of the scheme on their company.

In total, 25 respondents provided completed questionnaires on 32 s 166 employee share purchase schemes. The sample of companies" included in this paper account for

1 There was an important change in the legislation effective from April 1980 when the maximum size of the loan was increased from $\$ 1560$ to $\$ 2340$. Analysis indicated two points of note. Firstly, some firms had taken advantage of this change to top up their schemes. Secondly, more than half of the schemes introduced after this date had a maximum loan size less than $\$ 2000$.

2 A detailed breakdown of the response information is as follows: No response 70 ( 33 percent). No employee share scheme 103 ( 48 percent). Other (non-s166) employee share scheme 14 ( 7 percent)
and s166 scheme 25 ( 12 percent).

3 An analysis of total assets. profitability and turnover indicated that the median company in the sample would have ranked approximately number 25 of the companies listed on the New Zealand
Stock Exchange. 
approximately half of the schemes approved by the Commissioner. This response rate is biased downwards insofar as scheme approval is a necessary, but not sufficient. condition for scheme implementation. Furthermore. since implementation can follow approval with some delay. the number of schemes implemented in 1984 exceeded scheme approvals in that year. Table I contains information on the time profile of scheme initiations as indicated by respondents relative to the information provided by the IRD.

Table 1: Comparison of sample with data provided by the Inland Revenue Department, year ended 31st March

\begin{tabular}{lcc}
\hline Year & $\begin{array}{l}\text { Number } \\
\text { Approved }\end{array}$ & Sampled \\
\hline $1976-1979$ & 16 & 7 \\
-1980 & 6 & 4 \\
-1981 & 2 & 2 \\
-1982 & 9 & 5 \\
-1983 & 7 & 2 \\
-1984 & 2 & 3 \\
-1985 & 9 & 2 \\
Total & 51 & 25 \\
\end{tabular}

\section{Results}

\section{Scheme characteristics}

A summary of the details of s166 employee share schemes is presented in Table 2. The main restriction on eligibility for participation in share schemes was in terms of a qualifying period of employment. In 26 cases, schemes restricted eligibility to employees with a minimum full-time employment of 1 year, with the median qualifying employment period being 2 years. The maximum qualifying employment period allowable under the Act is 3 years. In addition, 17 schemes further restricted eligibility by excluding part-time employees.

The imposition of eligibility requirements substantially reduced the number of employees able to participate in approved s166 schemes. On average, the proportion of employees eligible to participate, relative to the total workforce, was 58.8 percent. Only 2 schemes were open to all employees not specifically excluded by the statutory restrictions detailed in the Act. In 26 cases, respondents indicated part-time employees did not constitute a significant part of the employee share purchase scheme.

Typically the life of the schemes conformed to the statutory requirements of a minimum 3 year period, although 4 schemes further extended the period during which eligible participants could not sell their shares. Similarly the longest scheme life was 5 years which corresponds to the maximum period under the provisions of the Act whereby the company can claim the notional 10 percent interest deduction on the amount of loans to employees.

The employees were given, on average, just over 4.6 weeks to decide whether to participate in the offer. Two schemes restricted the offer period to as short as 2 weeks, whilst the maximum exercise period was 8 weeks. These results indicate employees were typically given an offer period which compares favourably to distributions of seasoned stock.

On average, employers typically offered shares at considerable discounts relative to current market prices. The mean purchase price discount at issuance was 24 percent. Although the minimum discount was only 9 percent, 6 companies offered their shares at a discount in excess of 33 percent. These results indicate employers took substantial advantage of the statutory requirement that the issue price must not exceed current market value.

Table 2 also contains useful information on the administrative aspects of employee share purchase schemes. As a matter of administrative convenience, all schemes specified a minimum share entitlement per employee. In 11 cases, responding firms indicated the scheme required shareholder approval at an Annual General Meeting or Extraordinary General Meeting. Other firms may have had such powers written into their Articles of Association at 
the time of incorporation or passed at a meeting some considerable time ago. Furthermore, in all but 3 schemes, shares were made available by the issuance of new equity rather than by open purchase on the stock market. Trustees financed the loan capital to assist employee purchases exclusively by the internal funds of the company vis-a-vis external borrowing.

Table 2: Basic details of the s166 employee share purchase schemes

\begin{tabular}{|c|c|c|c|}
\hline & Mean & Maximum & Minimum \\
\hline Percentage of employees eligible & 58.8 & 100.0 & 12.1 \\
\hline Maximum permitted value, $\$$ & 1647 & 2340 & 600 \\
\hline Minimum permitted value, $\$$ & 305 & 652 & 44 \\
\hline Face value of the discount, $\$$ & 553 & 1260 & 80 \\
\hline Discount as a proportion of & & & \\
\hline $\begin{array}{l}\text { market price } \\
\text { Period for accentance weeks }\end{array}$ & 0.24 & 0.49 & 0.09 \\
\hline Period for acceptance, weeks & 4.6 & 8.0 & 2.0 \\
\hline Life of the scheme, months & 39 & 60 & 36 \\
\hline $\begin{array}{l}\text { Qualifying term of employment, } \\
\text { months }\end{array}$ & 23 & 36 & 3 \\
\hline
\end{tabular}

\section{Analysis of potential and actual benefits conferred on employees}

The financial benefits ${ }^{4}$ of participating in a s166 scheme are twofold. First, the shares are invariably issued at a discount to market price. Second, participating employees receive an interest free loan to fund their share purchase.

Table 3 provides 2 different estimates of the present value of the issue price discount and the interest free loan. The first estimate assumes the employee purchases the maximum share entitlement as specified in the questionnaire or otherwise implicit in the legislative constraint on the total cost of an employee share purchase. The second estimate assumes the employee purchases the average shareholding actually taken up in his/her company scheme.

The purchase price discount and interest savings benefit varied considerably across respondent companies. However, despite this variation each component made an approximately equivalent contribution, at the aggregate level, to the total benefit. On average, the value of the total benefit conferred to an employee was \$536. At a marginal rate of taxation of 35 percent, this is equivalent to an increase in an employee's weekly pay packet of $\$ 5.73$ over the term of the scheme.

\section{Employee participation rates}

Despite the magnitude of the economic benefits conferred by s166 schemes, not all eligible employees chose to participate. Figure 1 provides an analysis of employee participation rates along 2 dimensions: (i) the proportion of eligible employees who exercised their right to participate and (ii) the degree or extent to which these participating employees exercised their
maximum share entitlement.

On average, 45 percent of the offered shares were not accepted because only 55 percent of the eligible employees sought to take part in the scheme. Furthermore, 9.5 percent of the offered shares were not accepted because participating employees decided not to exercise their maximum share entitlement. Thus, the failure to attract full acceptance is more related to an inability to attract employees to participate in the scheme per se, rather than the failure to convince participating employees to exercise their rights to the fullest. 
Table 3: Economic benefit of the schemes in present value dollars (a)

Mean Maximum Minimum $\begin{aligned} & \text { Standard } \\ & \text { deviation }\end{aligned}$

Maximum offered present value

$$
\text { of discount (b) }
$$

Actual present value of discount (b)

Maximum offered present value of interest free loan (c)

Actual present value of interest free loan (c)

Maximum offered total present value

Actual total present value

$\begin{array}{llll}373 & 801 & 53 & 211 \\ 301 & 675 & 53 & 170 \\ 334 & 694 & 113 & 165 \\ 263 & 625 & 110 & 124 \\ 684 & 1,293 & 192 & 321 \\ 536 & 1,212 & 192 & 237\end{array}$

\section{Notes:}

(a) A risk-adjusted discount rate of 15 percent per annum is assumed to reflect the time value of money and the inherent riskiness of share purchase.

(b) Calculated by discounting the difference between the market value of the shares and their issue value over the life of the scheme.

(c) The interest rate saving is computed as the present value of the difference between: (i) the annuity equivalent. A. of a loan with accrued interest annualised at a rate of 15 percent per annum, assuming uniform monthly repayments and (ii) the uniform monthly repayments, $R$, assuming the loan is interest free.

(d) A Wilcoxon matched-pairs signed-ranks test $(n=26)$, comparing the maximum offered present value of discount with maximum offered present value of interest free loan, produced a z(calc) of 0.114 which is statistically significant at the 90.9 percent level for a two-tailed test.

Figure 1: Analysis of participation rates

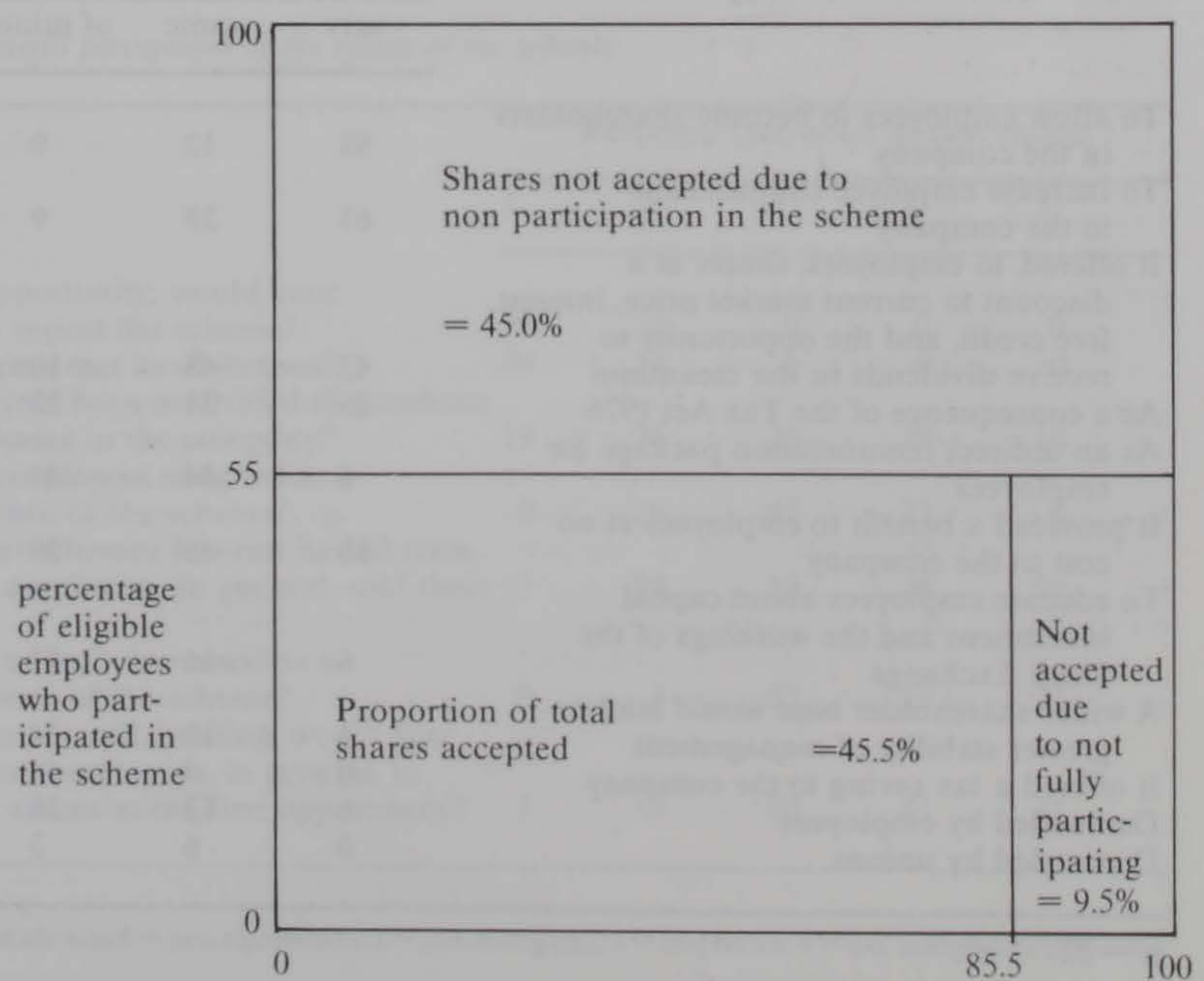

Average investment as a percentage of the maximum permitted value 
In an attempt to explain variations in participation rates between schemes the relationship between the participation rate and the characteristics of discount benefit, interest savings benefit, scheme life and length of offer period, was investigated. A priori, we would expect the longer the offer period and the larger the discount and interest savings benefit, the more likely employees would participate. Conversely, the longer the restrictive period of the scheme the lower the participation rate.

In general these expectations were confirmed by an analysis of the signs and magnitudes of partial correlation coefficients between scheme participation rates and the variables identified above. Scheme participation rates were positively and statistically significantly related to the size of the discount benefit $(\alpha=10 \%)$ and the length of the offer period $(\alpha=1 \%)$. Similarly, scheme participation rates were negatively and statistically significantly related to the length of the life of the scheme $(\alpha=1 \%)$. In contrast the partial correlation coefficient of the interest savings benefit was not statistically significant. This indicates that, after controlling for the effects of the 3 other variables, the size of the interest savings benefit had no effect on the degree of participation.

\section{Employer reasons for the scheme}

The questionnaire also sought the reasons company management gave for introducing their schemes. Respondents rated the importance of potential "reasons or influences" for introducing their schemes using a 4 point scale ranging from $1=$ "very important" to $4=$ "of no importance". Table 4 presents a summary of these employer responses.

Table 4: Reasons for the scheme

To allow employees to become shareholders in the company

To increase employee commitment to the company

It offered, to employees, shares at a discount to current market price, interest free credit, and the opportunity to receive dividends in the meantime

As a consequence of the Tax Act 1976

As an indirect remuneration package for employees

It provided a benefit to employees at no cost to the company

To educate employees about capital investment and the workings of the Stock Exchange

A wider shareholder base would lead to greater stability of management

It offered a tax saving to the company

Demanded by employees

Demanded by unions

Response in terms of importance, as a percentage

\begin{tabular}{cccc}
\hline very & quite & of minor & of no \\
\hline 88 & 12 & 0 & 0 \\
63 & 28 & 9 & 0 \\
& & & \\
& & & \\
42 & 45 & 10 & 3 \\
25 & 31 & 22 & 22 \\
6 & 44 & 44 & 6 \\
10 & 45 & 23 & 23 \\
& & & \\
6 & 16 & 47 & 31 \\
3 & 13 & 34 & 50 \\
0 & 9 & 44 & 47 \\
6 & 13 & 16 & 65 \\
0 & 6 & 3 & 91 \\
& & & \\
\hline & & &
\end{tabular}

$\mathrm{n}=32$ 
The prime reasons for the introduction of the schemes were to encourage employees to become shareholders in the company and to increase employee commitment. Employers, similarly, also rated the opportunity to provide interest free loans to enable employee purchase of shares at a discount relatively highly. These results are consistent with prior investigations of employee share schemes.

In addition, employers rated the advent of the $1976 \mathrm{Tax}$ Act as a moderately important factor influencing their decision to implement their scheme. Employers also rated the opportunity to provide an indirect remuneration moderately highly. However, whilst the benefits conferred on employees were considered to be moderately important in this regard. the possible tax savings to the company were perceived to be of "minor" to "no importance". This is inconsistent with the view that the notional tax relief of 10 percent per annum has not fully recompensed the Trustee, particularly in the past few years, for providing the loans to employees.

By way of contrast, employers rated employee and trade union pressure as being of virtually no importance in their decision. This result is consistent with previous evidence which suggests that trade unions were not consulted prior to the introduction of such schemes. Furthermore, the use of the schemes as an educational device about capital markets and the working of the Stock Exchange were not rated highly. The respondents did not support the view that employee share schemes are a means of diversifying shareholder bases to alleviate control problems.

\section{General perceptions}

The final section of the questionnaire asked the respondents to indicate their general perceptions of the effects of the share purchase scheme on their company. Respondents recorded their perception on a 5 point scale ranging from $1=$ "yes, significant" to $5=$ "no, significant". The general perceptions of employers are summarised in Table 5.

In general, employers indicated the initiation of employee share purchase schemes had made little or no significant contribution towards decreasing employee turnover or diminishing union un rest. Despite this perception employers were generally satisfied that the schemes had fulfilled their original objectives, and that given the opportunity, their company would repeat the scheme. A criticism of the survey is that it did not ask the appropriate questions to solicit the manner in which the companies were satisfied.

Table 5: General perceptions of the effects of the scheme

\begin{tabular}{|c|c|c|c|c|c|}
\hline & \multicolumn{5}{|c|}{ Response (see note) as percentage } \\
\hline & 1 & 2 & 3 & 4 & 5 \\
\hline $\begin{array}{l}\text { Given the opportunity, would your } \\
\text { company repeat the scheme? }\end{array}$ & 91 & 9 & 0 & 0 & 0 \\
\hline Has the scheme met its objectives? & 59 & 34 & 6 & 0 & 0 \\
\hline Have employees been motivated to purchase & & & & & \\
\hline further shares in the company? & 19 & 26 & 26 & 19 & 10 \\
\hline $\begin{array}{l}\text { Have fewer employees resigned as a } \\
\text { consequence of the scheme? }\end{array}$ & 0 & 26 & 45 & 23 & 6 \\
\hline $\begin{array}{l}\text { If one of your schemes has run its full term. } \\
\text { have the employees, in general, sold their } \\
\text { shares? }\end{array}$ & 5 & 24 & 19 & 14 & 38 \\
\hline $\begin{array}{l}\text { Has "union unrest" decreased as a } \\
\text { consequence of the scheme? }\end{array}$ & 0 & 3 & 55 & 19 & 23 \\
\hline $\begin{array}{l}\text { If your scheme is still running, would you } \\
\text { expect your employees, in general, to } \\
\text { sell their shares at the first opportunity? }\end{array}$ & 3 & 3 & 10 & 41 & 41 \\
\hline
\end{tabular}

Note:

The response scale was 1 =yes, significant: $2=$ yes. marginal: $3=$ uncertain: $4=$ no. marginal and $5=$ no. significant. 


\section{Michael Firth, Stephen Keef and Ross Mear}

In addition employers of schemes which had elapsed indicated that, in their opinion, very few employees had sold their shares since the time of transfer from the Trustee. Respondents representing those companies where the schemes were still in operation similarly indicated that. in their opinion. their employees would not sell their shares at the first available opportunity.

\section{Concluding Remarks}

Existing evidence on the incidence of employee share ownership schemes pre-dates the introduction of $\$ 166$ legislation and is clearly deficient. This study sought to remedy this deficiency and provides preliminary evidence on employee share ownership schemes in publicly listed companies.

The principal results of this study indicate that despite the Government's willingness to legislate and provide tax incentives, relatively few listed companies have followed this initiative and implemented s166 schemes. IRD sources indicate that less than a quarter of the listed companies have obtained the Commissioner's approval throughout the period 1976 to 1985.

Although these companies have offered shares to their employees at apparently advantageous rates, not all eligible employees chose to participate. The results of our preliminary analysis suggest participation rates were systematically related to the size of the financial benefit, the length of the offer period and the life of the scheme. Further research is required in order that we can more fully understand the individual motivations for this form of worker participation.

\section{References}

Fogelberg, G (1975) Employee participation: its meaning and implications for New Zealand business. Commentary Paper No 2, Department of Business, Victoria University of Wellington

Kirk, A (1984) Corporate funding and control: a trade union viewpoint 75 th Anniversary Convention, New Zealand Society of Accountants, Christchurch.

Smith. D F (1978) A critique of worker participation in New Zealand Journal of industrial relations 3: $71-79$

Smith, D F (1979a) Developments in workers' participation in management in New Zealand International Industrial Relations Association, Fifth World Congress, Paris.

Smith, D F (1979b) Developments in worker participation in New Zealand New Zealand journal of industrial relations 21 (1); 35-50.

Stephens, R J (1982) A framework for analysing worker participation in management New Zealand journal of industrial relations 7: 23-27.

Trott. R G (1977) Worker participation: a trade union viewpoint New Zealand Federation of Labour bulletin September, 10-12.

Turkington, D J (1980) The quest for worker participation in New Zealand Labour and employment gazette 30: 34-36.

Young. F J L (1978) Worker participation in management in New Zealand: a survey Typescript. Industrial Relations Centre. Victoria University of Wellington. 